\title{
Regulation of light attenuation and eelgrass Zostera marina depth distribution in a Danish embayment
}

\author{
Birgit Olesen* \\ Department of Plant Ecology, University of Aarhus, Nordlandsvej 68, DK-8240 Risskov, Denmark
}

\begin{abstract}
The distribution of eelgrass Zostera marina L. has declined significantly throughout a Danish embayment, the Limfjord, during the past 2 decades, parallel to increased nutrient input and reduced light penetration. In this study monthly measurements of Secchi depth from 1986 to 1989 were related to concentrations of nutrients, phytoplankton biomass (as chl a) and resuspended particles (mineral and organic) to evaluate their influence on water turbidity within 10 different basins of the Limfjord. The overall median concentrations of total $\mathrm{N}\left(0.87 \mathrm{mg} \mathrm{l}^{-1}\right)$ and total $\mathrm{P}\left(0.072 \mathrm{mg} \mathrm{l}^{-1}\right)$ were high, and total $\mathrm{N}$ accounted for $55.6 \%$ of the spatial variability in the chl a concentrations. Secchi depth transparency was highly variable as a result of seasonal fluctuations rather than spatial differences. Within all 10 basins the seasonal changes in Secchi depth were closely related to suspended particle concentrations $\left(R^{2}=0.408\right.$ to 0.667$)$. Suspended inorganic matter could account for more of the variability in attenuation than chl $a$ in half of the basins, and was closely related to wind-induced sediment suspension. Episodes of high water turbidity associated with high wind activity are, therefore, likely to influence the areal distribution of eelgrass within the Limfjord. Reduction in nutrient loading is expected to increase water clarity as suggested by the direct relationship of chl a to total $\mathrm{N}$. The impact is limited, however, by high levels of suspended mineral particles, such that Secchi depth transparency, closely related to eelgrass depth penetration, is only likely to increase by 10.6 to $17.5 \%$ following a 2fold reduction in phytoplankton biomass. Continued resuspension following the long-term perturbation of the entire embayment is, therefore, likely to constrain eelgrass colonization following nutrient abatement.
\end{abstract}

KEY WORDS: Eutrophication - Secchi depth Phytoplankton - Resuspension - Zostera marina

\section{INTRODUCTION}

Benthic macrophytes support an important fraction of the high primary productivity found in most shallow coastal waters of temperate regions (Mann 1982). Increasing nutrient loading, however, often leads to increased abundance of phytoplankton and epiphytes and, thus, to reduced light availability to submerged macrophytes (Sand-Jensen \& Borum 1991). As light availability is a major determinant of shoot density and biomass within seagrass meadows (Backmann \& Barilotti 1976) and their abundance with depth (Dennison 1987, Duarte 1991, Sand-Jensen et al. 1994b), eutroph-

•E-mail: biobebo@aau.dk ication often leads to a catastrophic mortality of deepgrowing plants, resulting in a decline of areas supporting seagrass growth. Hence, increased nutrient loading may be associated with a shift from dominance of rooted macrophytes to dominance of phytoplankton and ephemeral macroalgae, which are characterized by fast biomass turnover and profound seasonal fluctuations in abundance (Borum 1985, Sand-Jensen \& Borum 1991, Duarte 1995).

In shallow coastal environments tidal and windinduced currents often have a large impact on water turbidity (Ward et al. 1984, Gabrielson \& Lukatelich 1985, Carter et al. 1994, Pedersen et al. 1995). Dense seagrass meadows may, however, dampen the extent of sediment suspension as the plants provide physical protection against water turbulence and stabilize sur- 
face sediments (Fonseca et al. 1982, Ward et al. 1984). Eutrophication, leading to vegetation changes and reduced abundance of seagrasses, may increase sediment resuspension and, eventually, shoreline erosion (Christiansen et al. 1981). These changes will, in turn, further reduce light availability to the surviving seagrass meadows. Consequently, seagrass decline due to increased nutrient loading is likely to accelerate, through a series of feedback mechanisms.

In Limfjorden, a shallow and soft-bottom Danish embayment, the submerged vegetation is dominated by eelgrass Zostera marina L. However, the present distribution of eelgrass is greatly reduced compared to early records. At the beginning of this century, prior to the massive eelgrass 'wasting disease', vast eelgrass meadows covered approximately $25 \%$ of the total area and extended down to between 3.0 and $5.5 \mathrm{~m}$ (Ostenfeld 1908). In the late 1980s the depth limit of eelgrass was 1.5 to $4.0 \mathrm{~m}$, and the areal coverage was reduced to only half of that in 1901 (Olesen 1993). The major decline in eelgrass abundance observed within the Limfjord has taken place during the past 2 decades (Bio/consult 1990b). This development suggests that the low areal coverage of eelgrass today is the result of recent changes in water quality accompanying increased nutrient loading and water turbidity (Limfjordskomiteen 1989).

The objective of this paper is to evaluate the influence of phytoplankton and suspended particles on water transparency in 10 different regions of the Limfjord, and their importance to present-day depth distribution of eelgrass. The possible reasons for the observed differences in light conditions among sites are discussed, based on nutrient loading and potential wind-driven sediment resuspension.

\section{METHODS}

Study area. The Limfjord is a eutrophic shallow, brackish water area, with a mean depth of about $4.9 \mathrm{~m}$ and a surface area of $1500 \mathrm{~km}^{2}$ The fjord is connected to the open waters of the North Sea to the west and the Kattegat to the east through narrow entrances (Fig 1) and is characterized by small tidal amplitude $(<0.5 \mathrm{~m})$. The dominant saltwater inflow is with westerly winds from the North Sea and the average salinity ranges from $32 \%$ in the west to $22 \%$ in the inner parts of the fjord. The Limfjord is surrounded by intensively cultivated fields and urban areas. Hence, the nutrient load is low in the western part of the Limfjord and increases towards the inner parts, being proportional to the supply of freshwater from the catchment area.

Sampling and analysis. The data presented were collected as part of a survey of the water quality of the Limfjord and include measurements from sampling positions at the center of 10 relatively distinct basins (Fig. 1). The size of the basins varied between 40 and $380 \mathrm{~km}^{2}$ and the mean depth between 1.6 and $7.4 \mathrm{~m}$. Measurements of Secchi depth and sampling took place monthly from March 1986 to December 1989. Water samples were collected just beneath the water surface and were analyzed for total nitrogen (total N) and phosphorus (total P), chlorophyll a (chl a) and particulate suspended matter. Total $\mathrm{N}$ was measured colorimetrically as nitrite after oxidation of unfiltered water samples with peroxidisulfate (Koroleff 1972), followed by reduction to nitrite through cadmium columns. Total $\mathrm{P}$ was determined as ortho-P following oxidation with peroxidisulfate (Koroleff 1976), Chl a concentrations were measured spectrophotometrically

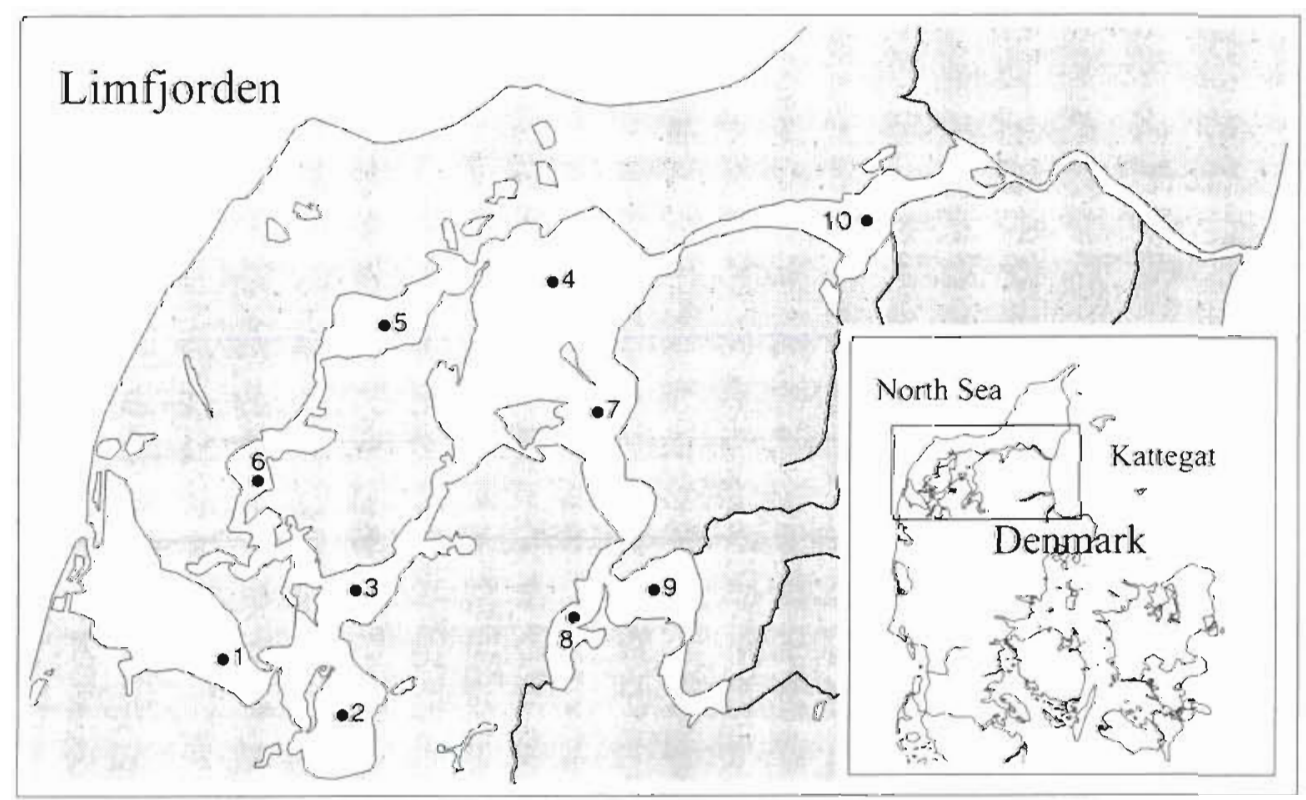

Fig. 1 Map of Limfjorden, Denmark, showing sampling stations 
after extraction in $96 \%$ ethanol (Wintermanns \& de Mots 1965). Water samples for analyses of suspended particulate matter were filtered onto preweighed Whatman GF/A filters, dried at $105^{\circ} \mathrm{C}$ and reweighed to determine dry weight. Suspended materials were further analyzed for the organic fraction (particulate organic matter, POM) as weight loss on ignition at $550^{\circ} \mathrm{C}$ and the inorganic fraction (particulate inorganic matter, PIM) as the ash content remaining.

Median values were used to represent the central tendency of all measured variables. The proportional contribution of temporal and spatial variation to the overall variance observed was obtained by performing a nested ANOVA for balanced designs (Sokal \& Rohlf 1981).

The relationship between Secchi depth and lightattenuating particles was expressed by the equation for vertical attenuation of light in water

$$
\left[\ln \left(I_{0} / I_{\mathrm{S}}\right)\right] S^{-1}=k^{\prime}+\alpha^{\prime} C
$$

where $I_{0}$ is surface light intensity, $I_{\mathrm{S}}$ is light intensity at the Secchi depth $(S), k^{\prime}$ is the light attenuation caused by factors other than suspended particles, $\alpha^{\prime}$ is the specific attenuation coefficient of particles, and $C$ is the concentration of particles (Lorenzen 1972, Kirk 1983). Assuming a constant ratio between $I_{0}$ and $I_{\mathrm{S}}$, Secchi depth can be described as inversely proportional to light attenuation (Lorenzen 1980)

$$
S^{-1}=k+\alpha C
$$

where $k$ is $k^{\prime}\left[\ln \left(I_{0} / I_{S}\right)\right]^{-1}$ and $\alpha$ is $\alpha^{\prime}\left[\ln \left(I_{0} / I_{S}\right)\right]^{-1}$.

The contribution of different particulate compounds to light attenuation is considered additive (Kirk 1983). Thus, the particulate light attenuation $(\alpha C)$ was partitioned into 3 fractions, describing attenuation caused by chl a $\left(\alpha_{\mathrm{chl}_{1}} C_{\text {chl }}\right)$, PIM $\left(\alpha_{\mathrm{PIM}} C_{\mathrm{PIM}}\right)$ and POM $\left(\alpha_{\text {POM }} C_{\text {POM }}\right)$. Multiple linear regression was applied to describe their relationship to Secchi depth. The relative importance of chl a and suspended organic and inorganic matter as light-attenuating components was assessed from partial correlation analysis. The distributions of all measured variables were approximately log-normal and were therefore transformed logarithmically prior to statistical analysis.

Wave-induced near-bottom orbital velocity above the bottom was estimated at each sampling site in order to describe the influence of wind-induced resuspension on variations in particulate matter load to the water column. Wind data were obtained at Thyborøn, a weather station located in the western part of the Limfjord. The orbital velocity was calculated according to Christiansen et al. (1992) and was based on measurements of wind fetches in 12 different directions and the water depths at the sampling positions (range among basins: 5.0 to $12.0 \mathrm{~m}$ ). The estimated orbital velocities were then weighed according to the frequency of each wind direction. The wind speed was held constant at $10 \mathrm{~m} \mathrm{~s}^{-1}$. This velocity was chosen as wind speed below this level is unlikely to cause measurable suspension at the deeper sampling stations (Sand-Jensen et al. 1994a). The monthly frequency of wind speeds at or above this level ranged between 4 and $42 \%$ during the study period. The bottom sediments were low in organic content (5 to $15 \%$ ) compared to the water column (38 to $54 \%$ ) (Limfjordskomiteen 1976). Resuspension should increase the proportion of mineral particles and the wave-induced orbital velocity was, therefore, related to the concentration of inorganic particles in surface waters.

Eelgrass depth distribution was determined by SCUBA diving along depth transects in each of the investigated basins during summer 1989 (Bio/consult 1990a, b, Petersen 1991). The maximum depth limits recorded were related to growing season (April-September) averages of Secchi depths, calculated from mean values of 2 to 6 measurements every month.

\section{RESULTS}

\section{Spatial and temporal variability}

Measured levels of nutrients, suspended particles and Secchi depths are presented as the overall median value, the upper and lower quartiles and the range (minimum and maximum values) for all stations and sampling dates (Table 1). The median concentration of total $\mathrm{N}\left(0.87 \mathrm{mg} \mathrm{l}^{-1}\right)$ was approximately 10 -fold higher than that of total $\mathrm{P}\left(0.072 \mathrm{mg} \mathrm{l}^{-1}\right)$, and both nutrients' levels were within the high range of nutrient concentrations measured in a comparative study of water quality in several Danish coastal areas (Sand-Jensen et al. 1994b). The concentrations of chl a during the $4 \mathrm{yr}$ sampling period ranged from 0.1 to $140 \mu \mathrm{g} \mathrm{l}^{-1}$ and were

Table 1. Secchi depth and concentrations of total N, total P, chl a and particulate inorganic (PIM) and organic (POM) matter measured within 10 different basins of the Limfjord. Data are presented as the overall median value, the upper and lower quartiles (25 and $75 \%$ fractiles) and the range

\begin{tabular}{|c|c|c|c|}
\hline Variable & Median value & $\begin{array}{c}\text { Upper and } \\
\text { lower quartiles }\end{array}$ & Range \\
\hline Total $N\left(\mathrm{mg} \mathrm{l}^{-1}\right)$ & 0.87 & $0.66-1.20$ & $0.29-4.00$ \\
\hline Total P $\left(\mathrm{mg} \mathrm{l}^{-1}\right)$ & 0.072 & $0.049-0.094$ & $0.014-0.270$ \\
\hline $\mathrm{Chl} a\left(\mu \mathrm{g} \mathrm{l}^{-1}\right)$ & 5.0 & $3.0-10.0$ & $0.1-140.0$ \\
\hline POM (mg l-1) & 2.7 & $1.9-3.6$ & $0.1-9.5$ \\
\hline $\operatorname{PIM}\left(\mathrm{mg} \mathrm{l}^{-1}\right)$ & 2.9 & $1.6-4.7$ & $0.1-40.6$ \\
\hline Secchi depth (m) & 2) 3.5 & $2.5-5.0$ & $0.5-11.3$ \\
\hline
\end{tabular}
(min.-max.) $(n=450)$ 
highly skewed, as 50\% of all measurements were below $5 \mu \mathrm{g} \mathrm{I}^{-1}$. Similarly, the median value of suspended inorganic matter $\left(2.9 \mathrm{mg} \mathrm{l}^{-1}\right)$ and organic matter $\left(2.7 \mathrm{mg} \mathrm{l}^{-1}\right.$ ) was several-fold lower than the maximum values encountered $\left(40.6\right.$ and $9.5 \mathrm{mg} \mathrm{l}^{-1}$, respectively). The Secchi depth ranged between 0.5 and $11.3 \mathrm{~m}$ with the majority of measurements $(75 \%)$ below $5.0 \mathrm{~m}$ and a median value of $3.5 \mathrm{~m}$.

Examination of the extent of variability in the measured components among basins compared to the temporal variability within each basin demonstrated that between 81.8 and $96.3 \%$ of the total variability was attributable to seasonal fluctuations (Table 2). Nutrients, suspended particle concentrations, and Secchi depth showed small changes among the locations in the Limfjord, and the median values only varied 1.8 to 3.3-fold among basins (data not shown).

Nutrient concentrations along the Limfjord were proportional to the supply of freshwater. Hence, salinity within the 10 Limfjord basins was significantly inversely related to total $N\left(R^{2}=0.746, p<0.01\right)$ and total $P$ content $\left(R^{2}=0.611, p<0.01\right)$. The relationship
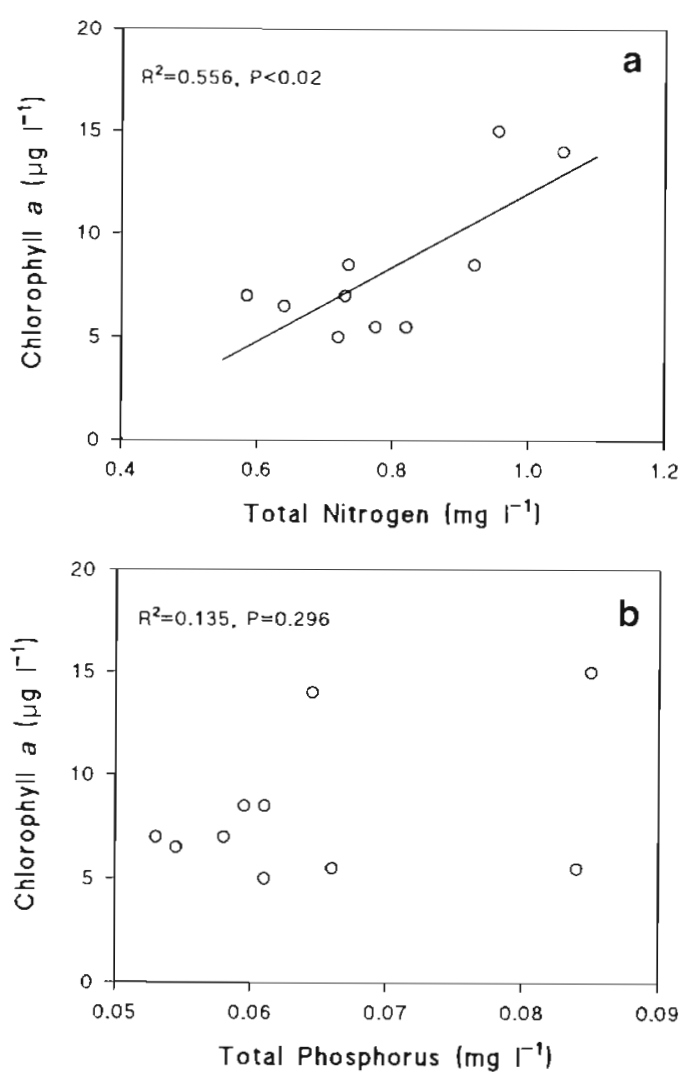

Fig. 2. Relationships between concentrations of chl a and (a) total $N$ and (b) total P. Each data point represents the growing season (April-September) median concentrations for each sampling station. Line describes the linear regression of chl a on total N. R ${ }^{2}$ coefficient of determination; $p$ : significance level
Table 2. Relative amount of variability (nested ANOVA) in total $N$, total. P, particulate inorganic (PIM) and organic (POM) matter, chlorophyll a (chl a), and Secchi depth among the 10 basins in the Limfjord compared to the seasonal variability within basins. The ANOVA test is based on monthly measurements during a $4 \mathrm{yr}$ perlod at 10 different stations. $F$-values are from the ANOVA testing differences among stations. $\cdots p<0.01, \cdots p<0.001$

\begin{tabular}{|lccc|}
\hline Variable & Among $(\%)$ & Within $(\%)$ & F-values \\
\hline Total N & 14.8 & 85.2 & $8.8 \cdots$ \\
Total P & 3.7 & 96.3 & $2.7 \cdots$ \\
PIM & 9.3 & 90.7 & $5.6 \cdots$ \\
POM & 4.6 & 95.4 & $3.2 \cdots$ \\
Chl a & 4.5 & 95.6 & $3.1 \cdots$ \\
Secchi depth & 18.2 & 81.8 & $11.0 \cdots$ \\
\hline
\end{tabular}

between nutrient concentrations and phytoplankton biomass was described from the growing season median concentrations of $\mathrm{chl} a$, total $\mathrm{P}$ and total $\mathrm{N}$. Chl a concentrations were directly related to total $N$ $\left(R^{2}=0.556, p<0.02\right)$, but not to total $P\left(R^{2}=0.135, p=\right.$ 0.296 ) (Fig. 2).

Concentrations of suspended inorganic particles were directly related to the estimated near-bottom orbital velocities $\left(\mathrm{R}^{2}=0.576, \mathrm{p}<0.01\right)$ (Fig. 3). The unexplained variability in concentrations of inorganic particles among stations is in part due to uncertainties in the estimated velocity. Also, variations in sediment grain size among stations and the effect of topography on local wind speeds are expected to affect the relationship between calculated orbital velocity and suspended inorganic matter. The relatively high $y$-intercept of the relationship suggests that other factors besides suspension of bottom sediments, such as ter-

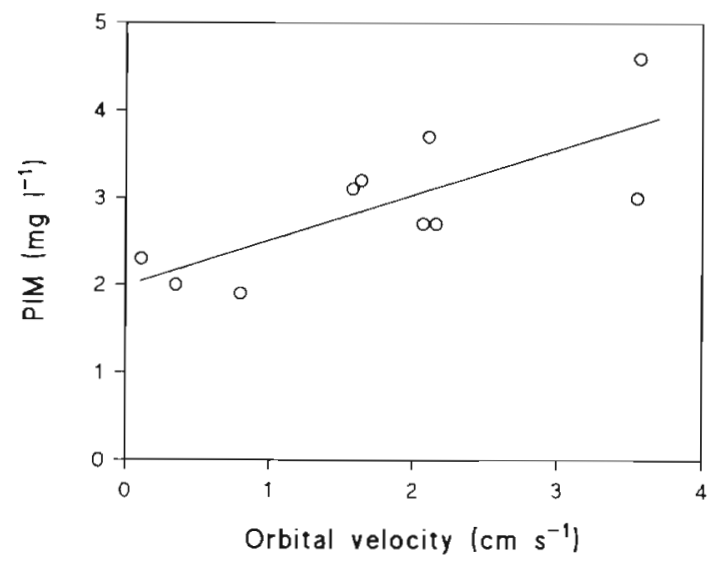

Fig. 3. Relationship between the overall median value of suspended inorganic matter (PIM) in the water column and estimated wave-generated near-bottom orbital velocity. Line describes the linear regression of PIM on orbital velocity $\left(R^{2}=\right.$ $0.576, p<0.01)$ 
restrial run-off and wind-and tidal-induced advective transport, have a major impact on the supply of inorganic particles to the water column.

\section{Suspended particles and Secchi depth}

Results from multiple regression analysis showed that the combined effect of chl a and suspended organic and inorganic matter on Secchi depth accounted for 40.8 to $66.7 \%$ of the total variability in Secchi depth (Table 3). Secchi depth did not respond significantly to changes in chl a, POM or PIM within all basins. Thus, POM was a poor descriptor of light attenuation and affected Secchi depth significantly in only half the basins investigated (Tables $3 \& 4$ ). The light attenuating effect of chl a $\left(\alpha_{c h l}\right)$ varied little among the 6 basins where relationships were significantly different from zero, showing slopes of Secchi depth against chl a concentrations from 0.137 to $0.233 \mathrm{~m}^{-2} \mathrm{mg}^{-1} \mathrm{chl} \mathrm{a}_{\text {, }}$ whereas the relations of Secchi depth and PIM were more variable (range for the slopes: 0.115 to $0.468 \mathrm{~m}^{-2}$ $\mathrm{g}^{-1}$ PIM) (Table 3). The $y$-intercept $(k)$, describing the background attenuation caused by dissolved organic matter and pure water only varied 1.4-fold among basins.

The relative impact of chl a, POM and PIM on Secchi depth was estimated from partial correlation analysis. The correlations between Secchi depth and suspended organic matter were weak within all basins (Table 4 , Fig. 4). For chl a the coefficient of determination $\left(R^{2}\right)$ ranged between 0.002 and 0.493 and exceeded that of PIM (range: 0.011 to 0.570 ) at 5 stations (Table 4). The relationship between Secchi depth and chl a was stronger in areas with high water clarity (Fig. 4). In contrast, suspended inorganic particles tended to dominate particulate light attenuation in turbid waters.
Table 4. Coefficients of determination $\left\{\mathrm{R}^{2}\right\}$, calculated from the partial correlations between Secchi depth (S) and concentrations of chl a and particulate inorganic (PIM) and organic matter (POM). Data from each sampling station (1-10) represent 45 measurements. ns: not significant, $\cdot p<0.05$ $\cdots p<0.01, \cdots p<0.001$

\begin{tabular}{|llll|}
\hline Stn & $S$ and chl a & S and POM & $S$ and PIM \\
\hline 1 & $0.009 \mathrm{~ns}$ & $0.008 \mathrm{~ns}$ & $0.570^{\cdots}$ \\
2 & $0.045 \mathrm{~ns}$ & $0.146^{\circ}$ & $0.329^{\circ}$ \\
3 & $0.002 \mathrm{~ns}$ & $0.111^{\circ}$ & $0.435^{\circ}$ \\
4 & $0.153^{\circ}$ & $0.064 \mathrm{~ns}$ & $0.203^{\cdots}$ \\
5 & $0.334^{\cdots}$ & $0.221^{\cdots}$ & $0.011^{\mathrm{ns}}$ \\
6 & $0.493^{\cdots}$ & $0.058 \mathrm{~ns}$ & $0.065 \mathrm{~ns}$ \\
7 & $0.177^{\cdots}$ & $0.101^{\circ}$ & $0.113^{\circ}$ \\
8 & $0.248^{\circ}$ & $0.139^{\circ}$ & $0.101^{\circ}$ \\
9 & $0.323^{\circ}$ & $0.050 \mathrm{~ns}$ & $0.134^{\circ}$ \\
10 & $0.252^{\circ}$ & $0.015 \mathrm{~ns}$ & $0.388^{\circ}$ \\
\hline
\end{tabular}

\section{Secchi depth and eelgrass depth limit}

During the growing season of 1989, the average Secchi depth ranged between 2.7 and $5.1 \mathrm{~m}$ among stations. However, marked temporal variability was apparent in all stations, and Secchi depth varied 2.0 - to 5.8 -fold at 9 of the stations and 12-fold at 1 station (not shown). The eelgrass depth limits ranged from 1.9 to $3.7 \mathrm{~m}$ and tended to increase with Secchi depth $\left(\mathrm{R}^{2}=\right.$ $0.413, \mathrm{p}<0.05$ ) (Fig. 5).

\section{DISCUSSION}

The Secchi depth transparency within the Limfjord was highly influenced by suspended particle concentrations, which accounted for 41 to $67 \%$ of the variability in Secchi depth (Table 3). Chl a was the major contributor to particulate light attenuation at half of the

Table 3. Results of multiple linear regression analysis of reciprocal Secchi depth $\left(S^{-1}, \mathrm{~m}^{-1}\right)$ against concentrations of chl a ( $\left.\mu \mathrm{g} \mathrm{l}^{-1}\right)$ and particulate inorganic (PIM, mg l-1) and organic (POM, mg l-1) matter. $\alpha_{c h}, \alpha_{\mathrm{PIM}}$ and $\alpha_{\mathrm{PON}}$ are the specific attenuation coefficients ( $\pm 95 \%$ confidence limits) of $\mathrm{chl} a$, PIM and POM, and $k$ is the background attenuation. $\mathrm{R}^{2}$ is the square of the correlation coefficient $(n=45)$

\begin{tabular}{|c|c|c|c|c|c|}
\hline Stn & $\begin{array}{c}\alpha_{\mathrm{chl}} \\
\left(\mathrm{m}^{-2} \mathrm{mg}^{-1}\right)\end{array}$ & $\underset{\left(\mathrm{m}^{-2} \mathrm{~g}^{-1}\right)}{\alpha_{\mathrm{pom}}}$ & $\underset{\left(\mathrm{m}^{-2} \mathrm{~g}^{-1}\right)}{\alpha_{\mathrm{PIM}}}$ & $\begin{array}{c}k \\
\left(m^{-1}\right)\end{array}$ & $\mathrm{R}^{2}$ \\
\hline 1 & $-0.079 \pm 0.128$ & $-0.017 \pm 0.226$ & $0.468 \pm 0.132$ & -0.641 & 0.611 \\
\hline 2 & $0.068 \pm 0.100$ & $0.240 \pm 0.186$ & $0.300 \pm 0.137$ & -0.688 & 0.408 \\
\hline 3 & $0.014 \pm 0.106$ & $0.256 \pm 0.232$ & $0.403 \pm 0.147$ & -0.789 & 0.526 \\
\hline 4 & $0.137 \pm 0.106$ & $0.165 \pm 0.208$ & $0.206 \pm 0.134$ & -0.810 & 0.485 \\
\hline 5 & $0.214 \pm 0.099$ & $0.152 \pm 0.094$ & $0.045 \pm 0.140$ & -0.866 & 0.471 \\
\hline 6 & $0.233 \pm 0.075$ & $0.086 \pm 0.111$ & $0.094 \pm 0.113$ & -0.847 & 0.570 \\
\hline 7 & $0.145 \pm 0.101$ & $0.161 \pm 0.156$ & $0.115 \pm 0.105$ & -0.788 & 0.420 \\
\hline 8 & $0.189 \pm 0.105$ & $0.289 \pm 0.230$ & $0.123 \pm 0.117$ & -0.808 & 0.667 \\
\hline 9 & $0.233 \pm 0.108$ & $0.105 \pm 0.147$ & $0.126 \pm 0.102$ & -0.783 & 0.604 \\
\hline 10 & $0.179 \pm 0.100$ & $0.050 \pm 0.133$ & $0.319 \pm 0.130$ & -0.815 & 0.597 \\
\hline
\end{tabular}




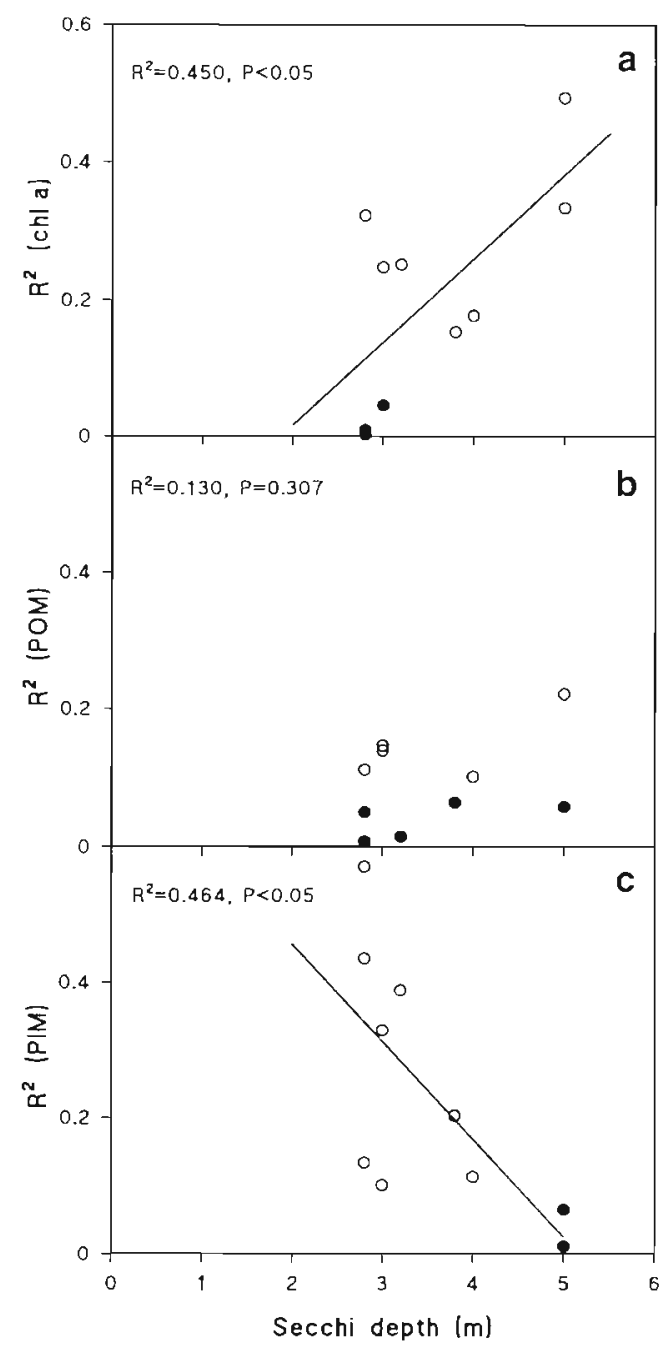

Fig. 4. Coefficients of determination $\left(R^{2}\right)$, describing the relative effect of light-attenuating particle concentrations on variability in Secr hi depth as a function of Secchi depth within 10 different Limfjord basins. $\mathrm{R}^{2}$ was calculated from partial correlation analysis between reciprocal Secchi depth and concentrations of (a) chl a, (b) particulate organic matter (POM) and (c) particulate inorganic matter (PIM). Significant relations $(\mathrm{p}<0.05)(\bullet)$; insignificant relations $(0)$. Lines describe significant relationships between Secchi depth and $R^{2}$ (chl) and between. Secchi depth and $\mathrm{R}^{2}$ (PIM)

stations investigated (Table 4). The impact of phytoplankton, expressed as chl a, on Secchi depth is presumably underestimated because chl $a$ is a measure of the standing phytoplankton biomass. Thus, the influence on Secchi depth of phytoplankton degradation products, such as dead particulate or dissolved organic matter, is not included. Accordingly, part of the light attenuation effect of POM is associated with phytoplankton productivity as indicated by the close relationship between concentrations of chl $a$ and POM among basins $\left(\mathrm{R}^{2}=0.689, \mathrm{p}<0.01\right.$, data not shown).

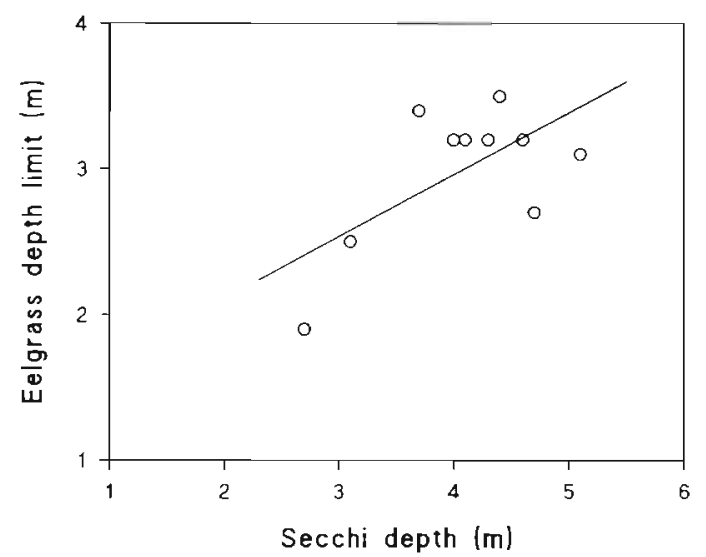

Fig. 5. Relationship between eelgrass depth limit and Secchi depth $(S)$ within the 10 investigated Limfjord basins. Line describes the regression equation: $Z_{\max }=0.425 S+1.259$, $\mathrm{R}^{2}=0.413, \mathrm{p}<0.05 . Z_{\max }$ : eelgrass depth limit

In Limfjord basins with weak or non-significant correlations between Secchi depth and chl $a$, Secchi depth was closely related to variability in suspended inorganic particles (Tables $3 \& 4$ ). Similar effects of suspended matter on the relationship between Secchi depth and chl a have been observed in comparisons of light climate among different freshwater lakes and imply that changes in Secchi depth are closely related to chl a only in the absence of high concentrations of suspended particles (Megard et al. 1980, Koenings \& Edmundson 1991, Phlips et al. 1995a). Hence, in water areas with high turbidity and moderate phytoplankton biomass Secchi depth does not necessarily reflect changes in nutrient load and the associated response of phytoplankton productivity.

The importance of inorganic suspended particles to light attenuation observed within some of the Limfjord basins (Table 4) is consistent with similar findings for shallow coastal waters elsewhere, where sources of high particle concentrations are river discharge and sediments resuspended by wind energy or tidal currents (Ward et al. 1984, Gabrielsen \& Lukatelich 1985, Campbell \& Spinrad 1987, Carter et al. 1994, Phlips et al. 1995b). Differences in concentrations of suspended inorganic particles among the Limfjord basins appear to reflect wind-induced suspension of sediments, as suggested by the direct relationship between the spatial distribution of inorganic matter in the water column and wind-induced orbital velocity (Fig. 3). Hence, high turbidity caused by sediment suspension is expected to occur periodically when wind speed exceeds a critical level, defined by basin morphometry and sediment grain size. Because wind-induced suspension of bottom sediments is greatest in shallow areas, the impact of suspended particles on light availability within areas with potential eelgrass growth 10.5 
to $4.0 \mathrm{~m}$ ) is presumably underestimated, as these results are based on open-water measurements (sampling depth: 5 to $12 \mathrm{~m}$ ). Within the shallow areas, vegetation cover will increase the critical wind velocity for sediment suspension, due to the sediment stabilizing effects of eelgrass populations (Fonseca et al. 1982, Ward et al. 1984). Thus, it is likely that the observed recession of eelgrass meadows has further increased the frequency of resuspension events within areas devoid of vegetation.

Differences in eelgrass depth limits among the Limfjord basins corresponded approximately to the variability in mean Secchi depth $\left(\mathrm{R}^{2}=0.413, \mathrm{p}<0.05\right.$; Fig. 5). Thus, for water areas with Secchi depths at $4.0 \mathrm{~m}$ the regression equation predicts that the maximum depth of eelgrass growth is about $3.0 \mathrm{~m}$. Assuming that $10 \%$ of surface light reaches the Secchi depth (Højerslev 1978), the average light intensity at this depth corresponds to $18 \%$ of surface light, which is slightly higher than the average light levels previously obtained for eelgrass (14\%; Sand-Jensen et al. 1994b) and for a range of seagrass species (11\%; Duarte 1991). However, the variance of the regression of depth limits on Secchi depth was high (Fig. 5), presumably because of errors associated with determination of eelgrass light compensation depths and the use of relatively few Secchi depth observations as a measure of integrated light climate.

The recent decline in eelgrass depth distribution within the Limfjord coincides with increased water turbidity associated with the intensified nutrient loading and phytoplankton productivity during the past decades (Limfjordskomiteen 1989). The direct relationship between chl $a$ and total N (Fig. 2) suggests, along with enrichment studies (Lyngby 1990), that phytoplankton biomass is mainly limited by nitrogen. A planned reduction in nutrient discharge to Danish waters by $50 \%$ for nitrogen around the year 2000 is, therefore, expected to increase Secchi depth transparency due to reduced phytoplankton production and, accordingly, to increase the depth at which adequate light is available for eelgrass growth and survival. Wind-induced sediment suspension is, however, likely to dampen the effect of reduced phytoplankton biomass on Secchi depth. Thus, provided that light attenuation caused by suspended mineral and organic particles remains unchanged, the relationships between Secchi depth and particle concentrations (Stns 4 to 10; Table 3) predict that Secchi depth is only expected to increase by 10.0 to $17.5 \%$ following a 2 fold reduction in concentrations of chl a and by 20.9 to $38.1 \%$ following a 4 -fold reduction in concentrations of chl a.

The predicted changes in water transparency upon reduced nutrient loading suggest that eelgrass recov- ery is likely to be constrained due to continued sediment resuspension. Gradual expansion of eelgrass meadows may, however, reduce the extent of sediment suspension due to increased physical protection of surface sediments against water turbulence (Fonseca et al. 1982, Ward et al. 1984) in a self-reinforcing process, leading to changes in Secchi depths exceeding those predicted above. Thus, assuming that concentrations of mineral particles in the water column are reduced by $50 \%$ following reestablishment of eelgrass meadows, the improvement of Secchi depths due to a 2-fold reduction in phytoplankton biomass would be twice the increase (19.8 to $41.2 \%$ ) predicted above.

Eelgrass colonization resulting from horizontal growth of rhizomes is very slow $\left(30 \mathrm{~cm} \mathrm{yr}^{-1}\right.$; Olesen \& Sand-Jensen 1994) and, therefore, the production of new patches from seedlings is critical to eelgrass recovery. However, negatively buoyant seeds result in a limited dispersal range away from reproductive populations (Orth et al. 1994). Long-distance dispersal is only likely to take place through detached fragments of flowering shoots, dispersed by current or wind action The time scale of these processes leading to eelgrass recovery needs further examination. However, the colonization of denuded areas, spatially separated from existing populations, is likely to proceed very slowly due to the low seed dispersal potential. On the other hand, once eelgrass vegetation has become established within an area, the colonization process is likely to accelerate due to the enhanced capacity of seed production as dense meadows develop, stabilize the sediments, and improve water clarity for further growth.

Acknowledgements. Limfjordskomiteen and the Danish Natural Science Research Council (grant no. 11-0835) provided the financial support for this work and the Limfjordskomiteen permitted use of the data presented. C. Christiansen kindly conducted the orbital velocity calculations. J. A. Christensen and E. M. Platz are thanked for logistic support and J. Borum. C. Duarte and K. Sand-Jensen for critically reviewing the manuscript.

\section{LITERATURE CITED}

Backman TW, Barilotti DC (1976) Irradiance reduction: effects on standing crops of the eelgrass Zostera marina in a coastal lagoon. Mar Biol 34:33-40

Bio/consult (1990a) Vegetationskortlœgning 1989: Kås Bredning, Sallingsund, de østlige bredninger, Langerak. LFK 50. Limfjordskomiteen, Viborg Amt

Bio/consult (1990b) Vegetationsovervågning på 21 transekter i Limfjorden 1989. LFK 51. Limfjordskomiteen, Viborg Amt

Borum J (1985) Development of epiphytic communities on eelgrass (Zostera marina) along a nutrient gradient in a Danish estuary. Mar Biol 87:211-218

Campbell DE, Spinrad RW (1987) The relationship between light attenuation and particle characteristics in a turbid estuary. Estuar Coast Shelf Sci 25:53-65 
Carter V, Rybicki NB, Landwehr JM. Turtora M (1994) Role of weather and water quality in population dynamics of submersed macrophytes in the tidal Potamic River. Estuaries $17: 417-426$

Christiansen $\mathrm{C}$, Christoffersen $\mathrm{H}$, Dalsgaard J, Nornberg $\mathrm{P}$ (1981) Coastal and nearshore changes correlated with dieback in eelgrass (Zostera marina). Sediment Geol 28 $168-178$

Christiansen C, Zacharias L, Vang T (1992) Storage, redistribution and net export of dissolved and sediment-bound nutrients, Vejle Fjord, Denmark. Hydrobiol 235/236:47-57

Dennison WC (1987) Effects of light on seagrass photosynthesis, growth and depth distribution. Aquat Bot 27:15-26

Duarte CM (1991) Seagrass depth limit. Aquat Bot 40 $363-377$

Duarte CM (1995) Submerged aquatic vegetation in relation to different nutrient regimes. Ophelia 41:87-112

Fonseca MS, Fisher JS, Zieman JC, Thayer GW (1982) Influence of the seagrass, Zostera marina L., on current flow. Estuar Coast Shelf Sci 15:351-364

Gabrielson JO, Lukatelich RJ (1985) Wind-related resuspension of sediments in the Peel-Harvey estuarine system. Estuar Coast Shelf Sci 20:135-145

Højerslev NK (1978) Daylight measurements appropriate for photosynthetic studies in natural sea water. J Cons Int Explor Mer 38:131-146

Kirk JTO (1983) Light and photosynthesis in aquatic ecosystems. Cambridge University Press, Cambridge

Koenings JP, Edmundson JA (1991) Secchi disk and photometer estimates of light regimes in Alaskan lakes: effects of yellow colour and turbidity. Limnol Oceanogr 36:91-105

Koroleff $F(1972)$ Determination of total nitrogen in natural waters by means of persulphate oxidation. In: Carlberg JR (ed) New Baltic manual with methods for sampling and analysis of physical, chemical and biological parameters International Council for the Exploration of the Sea (ICES), Charlottenlund

Koroleff F (1976) Determination of phosphorus. In: Grasshoff $\mathrm{K}$ (ed) Methods of seawater analysis. Verlag Chemie, Weinheim, New York, p 117-126

Limfjordskomiteen (1976) Limfjordsundersøgelsen 1973-75. Samlerapport. LFK 9. Limfjordskomiteen, Viborg Amt

Limfjordskomiteen (1989) Limfjorden - Vandmiljø: Udvikling og status 1974-1988. LFK 49. Limfjordskomiteen, Viborg Amt

Lorenzen CJ (1972) Extinction of light in the ocean by phytoplankton. J Cons Int Explor Mer 34:262-267

Lorenzen MW (1980) Use of chlorophyll-secchi disk relationships. Limnol Oceanogr 25:371-372

Lyngby JE (1990) Monitoring of nutrient availability and limitation using the marine macroalgae Ceramium rubrum (Huds.) C. Ag. Aquat Bot 38:153-161

This article was submitted to the editor
Mann KH (1982) Ecology of coastal waters. A system approach. Studies in ecology, Vol 8. Blackwel., Oxford

Megard RO, Settles JC, Boyer HA, Combs WS Jr (1980) Light, Secchi disks, and trophic states. Limnol Oceanogr 25: $373-377$

Olesen B (1993) Population dynamics of eelgrass. PhD thesis, University of Aarhus

Olesen B, Sand-Jensen K (1994) Patch dynamics of eelgrass Zostera marina. Mar Ecol Prog Ser 106:147-156

Orth RJ, Luckenbach M, Moore KA (1994) Seed dispersal in a marine macrophyte: implications for colonization and restoration. Ecology 75:1927-1939

Ostenfeld $\mathrm{CH}$ (1908) On the ecology and distribution of the grass-wrack (Zostera manina) in Danish waters. In: Petersen CGJ (ed) Report of Danish Biological Station to the Board of Agriculture, XVI. Centraltrykkeriet, København, p 1-62

Pedersen OB, Christiansen C, Laursen MB (1995) Windinduced long term increase and short term fluctuations of shallow water suspended matter and nutrient concentrations, Ringkøbing Fjord, Denmark. Ophelia 41. 273-287

Petersen DS (1991) Variation i epifytbiomasse på Allegrœes. MSc thesis, University of Aarhus

Phlips EJ, Aldrige FJ, Schelske CL (1995a) Relationships between light availability, chlorophyll $a$, and tripton in a large, shallow subtropical lake. Limnol Oceanogr 40 : $416-421$

Phlips EJ, Lynch TC, Badylak S (1995b) Chlorophyll a, tripton, color, and light availability in a shallow tropical innershelf lagoon, Florida Bay, USA. Mar Ecol Prog Ser 127: $223-234$

Sand-Jensen K, Borum J (1991) Interactions among phytoplankton, periphyton, and macrophytes in temperate freshwaters and estuaries. Aquat Bot 41:137-175

Sand-Jensen K, Borum J, Geerz-Hansen O, Jensen JN, Josefson AB, Møhlenberg F, Riemann B (1994a) Resuspension og stofomsœtning i Roskilde Fjord. Havforskning fra Miljøstyrelsen, nr. 51. Miljøstyrelsen, København

Sand-Jensen K, Nielsen SL, Borum J, Geertz-Hansen O (1994b) Fytoplankton- og makrofytudvikling i danske kystområder. Havforskning fra Miljøstyrelsen, nr. 30 . Miljøstyrelsen, København

Sokal RR, Rohlf FJ (1981) Biometry, 2nd edn. WH Freeman and Company, New York

Ward LG, Kemp WM, Boynton WR (1984) The influence of waves and seagrass communities on suspended particulates in an estuarine embayment. Mar Geol 59:85-103

Wintermanns JFGM, de Mots A (1965) Spectrophotometric characteristics of chlorophylls $a$ and $b$ and their phaeophytins in ethanol. Biochim Biophys Acta 109: $448-453$

Manuscript first received: June 30, 1995

Revised version accepted: November 29, 1995 